\title{
EDITORIAL 2020.1
}

O Curso de Mestrado em Direito da Universidade Metodista de Piracicaba apresenta mais uma edição de Cadernos de Direito tendo por tema "Os Direitos Fundamentais Coletivos e Difusos".

No ano de 2019, tanto o Curso de Mestrado em Direito, quanto a Revista Cadernos de Direito sofreram alterações em seus quadros docente e editorial, o que acarretou em um atraso nas publicações dos artigos submetidas naquele ano. Assim, essa edição tem o escopo de retratar as edições de 2019 não publicadas.

A produção de conhecimento no Programa de Mestrado em Direito da Universidade Metodista de Piracicaba (UNIMEP) tem sido guiada pela sua área de concentração de pesquisa, que é o estudo e a produção no campo dos Direitos Fundamentais Coletivos e Difusos.

Os textos aqui apresentados trazem essa linha de trabalhar com fatos e como o Direito é a eles aplicado, sempre com o pano de fundo da proteção dos direitos fundamentais coletivos e difusos.

Sob este viés, os artigos científicos publicados abarcam os temas:

1. DA VONTADE GERAL COMO PODER DE FATO E PODER DE DIREITO: DO EXERCÍCIO DA SOBERANIA POPULAR ENTRE A UNIDADE MULTÍPLICE DA SOCIEDADE (UNITAS ORDINIS) E A TOTALIDADE POLÍTICO-JURÍDICA E ECONÔMICO-SOCIAL DO ESTADO. O autor, com base na teoria de Rousseau, assinalou que consiste na condição sine qua non para o exercício da soberania popular, uma construção que convirja para as fronteiras que encerram a Constituição e o Estado, a Vontade Geral, envolvendo a possibilidade de articulação da totalidade dos homens enquanto indivíduos em sua concreticidade histórico-cultural e econômico-social, o que implica a universalidade concreta, que advém do conjunto de vontades e fato econômico que caracteriza a sociedade e a dinâmica das relações intersubjetivas.

2. O IMPACTO DA PANDEMIA PROVOCADO PELO CORONAVIRUS NO CENÁRIO EDUCACIONAL BRASILEIRO. A autora analisou, alguns dentre os vários efeitos da pandemia provocada pela disseminação da Covid-19 que impactaram o cenário educacional brasileiro, com o intuito de trazer o tema ao debate e, com isso, realizar um diagnóstico, mesmo que parcial, desses efeitos.

3. OS CONHECIMENTOS TRADICIONAIS ASSOCIADOS À BIODIVERSIDADE AMAZÔNICA: PROTEÇÃO JURÍDICA E SUSTENTABILIDADE. A autora analisou a inter-relação dos conhecimentos tradicionais dos povos da Amazônia com a sustentabilidade, 
tendo como objeto basilar a proposta de estudar a proteção jurídica aplicada aos conhecimentos tradicionais associados à biodiversidade amazônica.

4. A TRANSNACIONALIDADE E A PROTEÇÃO JURIDICA DOS CONHECIMENTOS TRADICIONAIS NA BOLÍVIA, COLÔMBIA, EQUADOR, GUIANAS, PERU, SURINAME E VENEZUELA. A autora examinou a transnacionalidade e a proteção jurídica dos conhecimentos tradicionais na Bolívia, na Colômbia, no Equador, nas Guianas, no Peru, no Suriname e na Venezuela, países integrantes da região amazônica, com o objetivo geral de analisar a proteção jurídica dos conhecimentos tradicionais associados à biodiversidade nos países que integram a região amazônica, considerando a imprescindível inter-relação dos conhecimentos tradicionais dos povos da Amazônia com a conservação ambiental.

5. RESPONSABILIDADE CIVIL POR DANO DIREITO AMBIENTAL. O autor estudou as leis que regulamentam o Direito Ambiental pátrio, verificando que desde seu princípio, na segunda metade do século XX, essas inovações já visavam garantir o equilíbrio entre o desenvolvimento sustentável e a qualidade de vida do ser humano, tanto para a geração da época, como também para as futuras, com vistas a que todos pudessem desfrutar dos recursos naturais tão ricos para a saúde humana. Trouxe-se também a discussão do princípio da prevenção e da precaução para a imposição da reparação dos danos ambientais, por meio da ação civil pública e a ação popular.

6. MULHERES MIGRANTES E TRABALHO DOMÉSTICO NO BRASIL E NO MUN$D O$. Os autores estudaram a migração feminina, de tal forma a pensar o seu deslocamento, opcional ou forçado, em busca de manutenção da própria sobrevivência e/ou a dos seus dependentes, bem como evidenciam que o gênero e a qualificação da mulher migrante serão decisivos para a determinação do posto de trabalho a ser ocupado no local do destino e as atividades a serem desenvolvidas.

7. CONFLITO ENTRE TEORIA DA VONTADE REAL E A TEORIA DA DECLARAÇÃO NA ESCADA PONTEANA. A autora investigou as teorias doutrinárias existentes e suscitadas, diante de um conflito envolvendo o elemento vontade dentro do negócio jurídico, questionando qual delas prevaleceria no atual sistema brasileiro.

A presente edição de Cadernos de Direito acredita que cada artigo aqui publicado possa contribuir de forma singular e efetiva, para a construção de um debate acadêmico produtivo e crítico do Direito, bem como de um conhecer jurídico alicerçado e atual. 